Kajian Jurnalisme

ISSN 2549-0559 (cetak) ISSN 2549-1946 (online)

Volume 03 Nomor 01 Tahun 2019

\title{
Sensitivitas Gender Media Online Detik.com
}

\author{
Rachma Mutia Bakhtiar, Nuryah Asri Sjafirah, Maimon Herawati \\ Program Studi Ilmu Jurnalistik, Fakultas Ilmu Komunikasi Universitas Padjadjaran \\ Email: rachmamutiab@gmail.com
}

\begin{abstract}
Detik.com, one of the most frequently accessed online media in Indonesia, is still gender bias. On the other side, this popular online media now also led by a woman. A further study is needed to know their gender sensitivity. This research used a qualitative method with a case study approach. The case study is one of strategy and analysis method in qualitative data which emphasizes the object's particular cases. The researcher used an in-depth or intrinsic case study method to understand more about gender sensitivity of editorial staff in detik.com. Research showed that the editorial staff of detik.com hasn't fully applied the gender sensitivity in their journalistic works. Due to a difference of understanding regarding gender-sensitive reporting; these staffs tend to not fully implement gender sensitivity because of the work \& business patterns in online media. Detik.com also hasn't fully committed to apply the gender sensitivity in their policy.
\end{abstract}

Keywords: gender, gender sensitivity, online media, mass media

\begin{abstract}
Abstrak
Detik.com merupakan salah satu media online yang masih bias gender. Padahal detik.com merupakan media online yang paling sering diakses di Indonesia. Di sisi lain, kini detik.com dipimpin oleh seorang perempuan. Untuk itu perlu dikaji lebih jauh bagaimana sensitivitas gender dalam redaksinya. Penelitian ini menggunakan penelitian kualitatif dengan pendekatan studi kasus. Studi kasus intrinsik lalu digunakan untuk memahami secara lebih baik dan mendalam tentang sensitivitas gender di tingkat redaksional detik.com. Hasil penelitian menunjukkan para penentu kebijakan di tingkat redaksional detik.com masih kurang menerapkan sensitivitas gender dalam pelaksanaan kerja jurnalistiknya. Selain karena belum seragamnya pemahaman terkait pemberitaan yang sensitif gender, para penentu kebijakan ini terkadang belum mempraktikkan sensitivitas gender karena terhalang pola kerja dan pola bisnis media online. Detik.com juga masih belum berkomitmen secara penuh untuk menerapkan sensitivitas gender di dalam kebijakan lembaganya.
\end{abstract}

Kata kunci: gender, sensitivitas gender, media online, media massa 
77 | Kajian Jurnalisme

ISSN 2549-0559 (cetak) ISSN 2549-1946 (online)

Volume 03 Nomor 01 Tahun 2019

\section{Pendahuluan}

Media massa merupakan salah satu agen sosialisasi gender karena turut menyebarkan dan melestarikan ideologi gender. Sayangnya, realitas media massa di Indonesia masih menunjukkan adanya bias gender, terutama terkait pemberitaan perempuan. Salah satu media yang kerap melakukan pemberitaan yang bias gender adalah detik.com. Bias gender terlihat dalam pemberitaan kasus yang menyangkut perempuan, yakni pada pemberitaan korban kekerasan seksual, atau dalam kasus kejahatan yang menyagkut perempuan seperti korupsi. Pemilihan kosa kata, bahasa, serta adanya opini wartawan dalam berita yang merugikan perempuan.

Pada kasus pemerkosaan atau pelecehan seksual, realita yang digambarkan oleh detik.com cenderung merugikan korban perempuan. Aprilia \& Jannah menjelaskan, hal tersebut dapat dilihat dari kosakata yang digunakan oleh detik.com untuk memberitakan kejadian pemerkosaan. Dalam pemberitaan, korban sering digambarkan memiliki tubuh yang molek, paras yang cantik, korban merupakan pekerja tempat karaoke, korban seorang janda, ataupun korban mengenakan pakaian seksi dan rok mini. Dengan menyampaikan hal tersebut, detik.com seakan ingin menjelaskan bahwa menjadi hal yang lumrah ketika pemerkosaan terjadi pada mereka dan bahwa pemerkosaan tersebut terjadi karena dipicu oleh korban (Aprilia \& Jannah, 2014).

Sementara itu, dalam merepresentasikan pelaku, Aprilia \& Jannah menjelaskan seringkali detik.com menggambarkan bahwa pelaku dalam keadaan khilaf, karena pengaruh minuman keras, ada masalah keluarga, ditinggal istri menjadi TKW, atau karena tidak dapat menahan nafsu birahi. Hal ini juga seakan memberikan sebuah toleransi kepada para pelaku pemerkosaan, bahwa pemerkosaan yang mereka lakukan di luar kendali mereka dan terjadi karena pengaruh minuman keras, khilaf, dan ketidakmampuan mereka menahan hawa nafsu. Dalam berita berjudul "Polisi Bekuk Pelaku yang Hendak Perkosa Karyawati di Tangerang" misalnya, detik.com menyajikan fakta korban menggunakan celana pendek. Fakta mengenai kondisi korban ini pun seolah mengisyaratkan bahwa korban menjadi pemicu peristiwa perkosaan karena atribut, yakni baju yang digunakan korban.

Pada kasus pemberitaan kasus korupsi yang menyangkut perempuan, realita pemberitaan yang dilakukan detik.com lebih sering di luar konteks, seperti soal tubuh dan penampilan pelaku, kehidupan pribadinya, dll. Hasil penelitian Ilyas menyebut detik.com dalam pemberitaan Malinda Dee dan Ratu Atut misalnya, lebih banyak menampilkan tubuh perempuan. Presentase ditampilkannya tubuh dalam pemberitaan dua perempuan tersebut sebanyak 12.7\% dan 2.5\%, sementara dalam pemberitaan Ahmad Fathanah dan Wawan, presentase pemberitaan detik.com hanya sebanyak $2.3 \%$ dan $0 \%$. Kemudian, dalam pemberitaan Ratu Atut, detik.com kerap menampilkan berita yang sensasional dan merendahkan perempuan (Ilyas, 2015).

Detik.com juga kerap mengangkat pemberitaan tentang perempuan-perempuan yang ada maupun dekat dengan pelaku. Dalam pemberitaan Jennifer Dunn dalam kasus Tubagus Chaeri Wardana alias Wawan, detik.com melakukan pemberitaan yang seolah menyiratkan 
bahwa karena Jennifer cantik, wajar saja jika Wawan memberikan mobil padanya. Hal ini seperti menunjukkan bahwa Jennifer turut andil dalam kasus korupsi Wawan karena kecantikan dan kemolekan tubuhnya, sekaligus menguatkan pandangan bahwa laki-laki tidak mampu untuk mengendalikan diri ketika berhadapan dengan perempuan yang cantik. (Ilyas, 2015)

Dalam kasus korupsi yang melibatkan hakim Mahkamah Konstitusi, Patrialis Akbar beberapa waktu lalu, detik.com juga memilih fakta perempuan bernama Anggita yang bersama dengan Patrialis saat ditangkap. Adanya opini lewat kata-kata 'cantik' atau kata ganti 'janda beranak satu' juga menyiratkan bahwa kondisi Anggita yang cantik dan merupakan seorang janda turut andil dalam kasus korupsi yang melibatkan sang hakim. Kata-kata 'cantik' yang merupakan opini tersebut ditaruh pada judul berita. Misalnya pada berita dengan judul "Ketua MK Tak Tahu Hubungan Wanita Cantik Anggita-Patrialis Akbar".

Menurut Ketua Dewan Pers Yosep Adi Prasetyo, meskipun saat ini perkembangan media di Indonesia cukup pesat, media memang masih jauh dari kepekaan terhadap perspektif gender (Prasetyo, 2016). Di era new media ini, media online tak luput dari pemberitaan yang bias gender. Hal ini karena pemberitaan seputar seks dan kriminal kini sering muncul di media online yang tujuannya untuk meningkatkan jumlah pembaca (viewer) atau klik demi meraih iklan.

Pemberitaan bias gender di media massa ini terjadi karena berbagai hal. Menurut Sutarso, pertama karena ideologi besar yang bersumber dari budaya patriarki tentang kesetaraan yang masih memasung sikap dan pemikiran para pekerja pers, yang kebanyakan masih didominasi laki-laki. Kedua, adanya kemungkinan belum dipahaminya konsep dan isu gender oleh para pekerja pers. Ini menyangkut perspektif dari wartawan atau editor media. (Sutarso, 2012)

Susunan redaksi Detik.com memang masih didominasi oleh laki-laki. data susunan redaksi yang dipampang dalam situs resminya, dari total 175 orang, perbandingan perempuan adalah 55 orang $(31,34 \%)$ dan laki-laki adalah 120 orang $(68,57 \%)$. Kebanyakan laki-laki juga masih menduduki posisi strategis penentu kebijakan. Meski begitu, ada hal yang menarik dari susunan redaksi detik.com. Terhitung sejak 1 November 2016, redaksi detik.com resmi dipimpin oleh seorang perempuan, Iin Yumiyanti, setelah pemimpin redaksi sebelumnya, Arifin Ashydad, mundur dari posisi puncak kariernya di detik.com.

Level pengambil keputusan pada media atau redaksi menjadi salah satu faktor yang perlu diperhatikan. Hal ini meliputi keberimbangan gender di antara para pengambil keputusan di organisasi media, yakni pemimpin redaksi, redaktur, kepala departemen, dan kepala desk. Apalagi, redaksi jugalah yang sangat menentukan konstruksi realitas yang dilakukan media massa.

Menurut Houtman Tahrun dan M. Nasir, peran perempuan yang maksimal dalam ruang redaksi pun kini menjadi salah satu dari sekian banyak cara untuk mewujudkan jurnalisme yang sensitif gender. Hal ini karena mereka memiliki kontribusi besar dalam menentukan isu-isu yang harus diangkat dari sudut pandang perempuan (Tahrun \& Nasir, 2016).

Detik.com yang kini dipimpin oleh seorang pemimpin redaksi perempuan, Iin Yumiyanti, salah satu perempuan yang berpengaruh dalam perjalanan detik.com. Dalam 
79| Kajian Jurnalisme

ISSN 2549-0559 (cetak) ISSN 2549-1946 (online)

Volume 03 Nomor 01 Tahun 2019

penelitian yang dilakukan AJI (Luviana, 2012), dijelaskan bahwa Iin Yumiyanti adalah sosok yang tak asing dengan isu-isu terkait gender. Ia pernah memberikan perhatian besar untuk peliputan mengenai Syekh Puji yang menikahi gadis di bawah umur dan pada kasus Sumiyati, tenaga kerja Indonesia di Arab Saudi yang mengalami penyiksaan.

Sebagai media online yang paling sering diakses tentunya membuat detik.com berperan sangat penting dalam sosialisasi konsep gender yang nantinya akan dianut dan dipahami masyarakat. Bagaimana sensitivitas gender detik.com dilihat dari penentu kebijakan di tingkat redaksi, serta perubahan kebijakan strategis mengenai gender dalam redaksional yang mungkin berubah di bawah kepemimpinan Iin Yumiyanti.

\section{Metode}

Metode yang digunakan adalah metode penelitian kualitatif dengan pendekatan studi kasus. Metode kualitatif adalah suatu prosedur penelitian yang menghasilkan data deskriptif berupa kata-kata tertulis dari orang-orang dan perilaku yang dapat diamati (Moleong, 2017). Pendekatan studi kasus dipilih karena studi kasus adalah salah satu strategi dan metode analisis data kualitatif yang menekankan pada kasus-kasus khusus yang terjadi pada objek analisis (Bungin, 2008). Studi kasus adalah uraian dan penjelasan secara komprehensif mengenai aspek seorang individu, kelompok (komunitas), program atau situasi sosial (Mulyana, 2010).

Berkaitan tentang sensitivitas gender di tingkat redaksi detik.com yang akan diteliti, penelitian studi kasus ini menggunakan jenis studi kasus intrinsik (intrinsic case study). Hal ini karena studi kasus intrinsik digunakan untuk memahami secara lebih baik dan mendalam tentang suatu kasus tertentu.

Data dikumpulkan melalui wawancara dan studi dokumen, dianalisis menggunakan teknik analisis data model interaktif menurut Miles \& Huberman. Menurut teknik analisis data ini, ada empat tahapan yang harus dilakukan, yakni: pengumpulan data, reduksi data, display data dan penarikan kesimpulan/ verifikasi (Herdiansyah, 2012).

\section{Hasil dan Pembahasan}

\section{Konsep Gender yang Dianut Para Penentu Kebijakan di Tingkat Redaksional detik.com}

Masing-masing penentu kebijakan di tingkat redaksional detik.com memiliki konsep gender individual yang berbeda. Masih ada yang berpendapat bahwa ada pembagian peran-peran gender, terutama bagi perempuan. Pembagian peran gender ini misalnya terkait perempuan sebagai ibu rumah tangga dan sebaiknya tidak bekerja, atau terkait pekerjaan tersebut cocok atau tidak untuk dilakukan perempuan.

Meski masing-masing penentu kebijakan memiliki pandangan yang berbeda terhadap konsep gender yang dianut secara individual, misalnya dalam berumah tangga, para penentu kebijakan di detik.com mengaku tidak lagi melihat perbedaan gender sebagai suatu masalah yang berarti di tempat kerja. Begitu juga dengan konsep gender yang berlaku di detik.com. Semua pekerjaan bisa dilakukan siapa saja, perempuan atau laki-laki berdasarkan profesionalitas dan kredibilitas. Walaupun pada beberapa kasus tertentu, memang tak dapat 
dipungkiri tetap ada pertimbangan-pertimbangan tertentu untuk pembagian kerja atau liputan berdasarkan jenis kelamin.

Hampir semua penentu kebijakan mengaku belum pernah menerima pelatihan seputar gender. Baru Pemimpin Redaksi Iin Yumiyanti yang mengaku pernah mengikuti pelatihan, itupun karena ia mendaftar sendiri di luar kantor. Pelatihan seputar gender menurut mereka biasanya diterima secara tidak langsung lewat seminar atau forum-forum yang dihadiri saat liputan.

Keikutsertaan pada pelatihan gender ini juga nampaknya masih didasari oleh minat atau tidaknya masing-masing individu, bukan perlu atau tidak. Iin Yumiyanti mengaku mengikuti pelatihan gender secara mandiri karena dirinya memang memiliki minat tersendiri terhadap isu gender dan cukup peduli terhadap isu-isu tersebut. Berkebalikan dengan Iin, Redaktur Pelaksana Detiknews Fajar Pratama menjelaskan bahwa dirinya belum pernah dan tidak tertarik untuk mengikuti pelatihan gender tersebut. Sementara itu Wakil Pemimpin Redaksi Elvan Dany menjelaskan bahwa dirinya merasa isu gender bukanlah masalah sehingga pelatihan terkait gender belum perlu diselenggarakan di detik.com.

Dalam melakukan kerja jurnalistiknya, para penentu kebijakan ini terkadang menemui hambatan karena konsep gender yang dipahami atau dianut secara individual berbeda dengan konsep gender kolektif media tempatnya bekerja atau berbeda dengan konsep gender yang dianut masyarakat luas. Menurut Iin Yumiyanti, budaya patriarki dan pelabelan dari masyarakat terhadap perempuan, apalagi yang menggunakan kerudung menjadi salah satu hambatan yang membuatnya tidak bisa mengambil semua isu liputan yang tersedia. Sebagai contoh, wartawan perempuan sulit untuk meliput di tempat hiburan malam atau tempat pelacuran.

\section{Kebijakan Redaksional detik.com Terkait Gender}

\section{Pembagian dan Fasilitas Kerja}

Tidak ada kebijakan khusus bagi perempuan ataupun laki-laki di detik.com. Tidak ada perbedaan kesempatan, beban kerja dan jenjang karir, serta penghargaan maupun hukuman. Semua dilakukan berdasarkan kompetensi individu wartawan dan kebutuhan detik.com. Begitu juga dalam perekrutan, tidak ada syarat khusus atau pengecualian yang berhubungan dengan gender. Semua dilakukan berdasarkan profesionalitas. Setelah diterima menjadi jurnalis, layaknya media massa pada umumnya, detik.com juga menerapkan sistem rolling. Pembagian kerja dilakukan berdasarkan posisi atau pos yang sedang membutuhkan di lapangan.

Untuk kasus atau situasi tertentu, pembagian pekerjaan atau isu peliputan dengan pertimbangan gender terkadang memang tidak dapat dipungkiri, namun menurut detik.com semuanya masih berdasarkan pertimbangan logis dan situasional. Misalnya ketika liputan salat IED ketika Hari Raya Idul Fitri atau isu liputan tersebut memang membutuhkan fisik yang kuat, biasanya laki-laki yang akan terpilih. Perempuan kerap ditempatkan untuk isu-isu ringan seperti lifestyle, bukan karena kesengajaan, namun lebih karena memang perempuan lebih banyak paham isu tersebut. Meski begitu, banyak juga laki-laki yang bekerja untuk isu tersebut karena memang mereka mampu dan mau. Topik gaya hidup atau lifestyle seperti dalam kanal 
81| Kajian Jurnalisme

ISSN 2549-0559 (cetak) ISSN 2549-1946 (online)

Volume 03 Nomor 01 Tahun 2019

wollipop memang lebih diketahui dan dikuasai perempuan, tapi laki-laki pun tetap ada karena mereka secara spesifikasi memenuhi syarat.

Detik.com memberikan beberapa fasilitas khusus bagi karyawan perempuan sesuai ketentuan peraturan ketenagakerjaan seperti cuti menstruasi atau haid selama 2 hari yang bisa digunakan setiap bulannya dan cuti melahirkan selama 3 bulan. Namun, sayangnya setelah pindah kantor ke Gedung Trans Media Juni 2017 lalu, detik.com belum memiliki ruang laktasi atau ruang menyusui sendiri. Selain itu, beban tanggungan asuransi bagi pekerja perempuan berbeda dengan laki-laki karena peraturan perusahaan dan ketenagakerjaan di tingkat menteri menyatakan bahwa pekerja laki-laki akan menanggung asuransi keluarga, termasuk istri dan anak, sementara perempuan hanya menanggung asuransinya sendiri.

Detik.com menerapkan sistem piket malam untuk pembagian tugas masing-masing wartawannya. Piket malam dimulai dari jam 6 sore sampai jam 10 pagi. Tidak ada perbedaan penugasan maupun fasilitas untuk laki-laki dan perempuan di malam hari kecuali untuk perempuan yang sedang hamil, baru melahirkan dan masih memiliki anak kecil. Mereka mendapat toleransi untuk tidak piket malam selama 2 tahun.

Detik.com rutin menyelenggarakan berbagai pelatihan jurnalistik bagi jurnalisnya, namun belum pernah menyelenggarakan pelatihan khusus terkait gender maupun pemberitaan sensitif gender. Biasanya detik.com mengirimkan jurnalis mereka jika ada seminar atau pelatihan terkait hal tersebut di luar kantor. Selain itu, menurut Wakil Pemimpin Redaksi detik.com Elvan Dany, Kementerian Perempuan juga pernah datang untuk membahas masalahmasalah atau isu-isu perempuan dan menanyakan bagaimana posisi atau kondisi perempuan yang bekerja di detik.com.

\section{Kebijakan Terkait Kerja Jurnalistik}

Detik.com tidak memiliki pedoman khusus maupun pedoman secara tertulis tentang bagaimana peliputan dan penulisan berita terkait isu gender, semua pedoman peliputan dan penulisan berita berpegang kepada kepada Kode Etik Jurnalistik dan Pedoman Media Siber yang telah disusun oleh Dewan Pers.

Selain itu, detik.com juga memiliki panduan yang disusun sendiri yang disebut "buku putih". Buku ini secara garis besar menjelaskan aturan-aturan atau kebijakan yang dimiliki detik.com dan panduan teknis termasuk pedoman berbahasa dan etika liputan. Menurut Iin, sejauh ini buku putih belum memuat informasi secara detail tentang aturan pemberitaan sensitf gender, namun buku ini akan terus diperbaharui secara berkala. Meski begitu, In menuturkan belum semua wartawan di detik.com memiliki buku ini. Kebanyakan aturan-aturan tambahan terkait kerja jurnalistik ini juga biasanya disampaikan kepada wartawan lewat email redaksi atau ketika rapat berlangsung. 
Kajian Jurnalisme

ISSN 2549-0559 (cetak) ISSN 2549-1946 (online)

Volume 03 Nomor 01 Tahun 2019

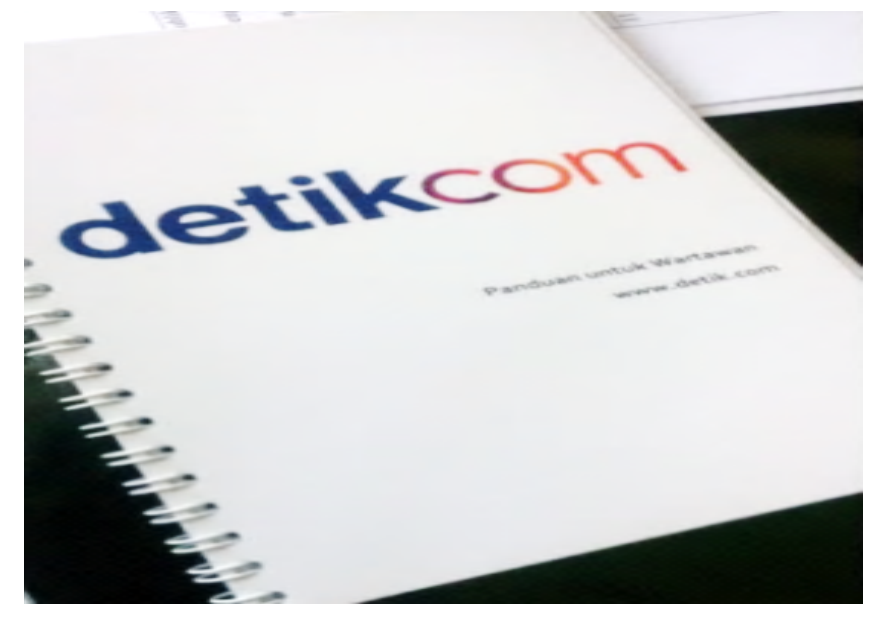

Gambar 1 Buku Putih detik.com

(Sumber: Observasi peneliti)

\section{Kanal terkait Gender dan Pemilihan Nara Sumber}

Di detik.com, berita-berita terkait perempuan umumnya ada di kanal detiknews. Selain di detiknews, untuk informasi terkait perempuan lainnya seperti gaya hidup, hal-seputar ibu dan anak maupun kesehatan masing-masing akan masuk di kanal wollipop, HaiBunda dan detikhealth. Situs HaiBunda terbilang baru karena diluncurkan Juli 2017 lalu. Kanal yang juga merupakan salah satu terobosan yang dikeluarkan Iin Yumiyanti ini berisi tentang informasi seputar ibu dan anak yang sebelumnya terangkum di kanal detikhealth. Peluncuran kanal ini untuk mengimbangi pembaca detik.com yang 70 persennya masih didominasi laki-laki.

Detik.com tidak membeda-bedakan narasumber laki-laki atau perempuan. Semua narasumber dipilih karena sesuai dengan apa yang dicari, bersedia diwawancara dan tentunya berdasarkan kredibilitas narasumber tesebut. Redaksi memiliki daftar narasumber terkait untuk mendukung pemberitaan terkait gender. Meski begitu detik.com mengakui minimnya perempuan sebagai narasumber berita masih menjadi salah satu masalah, terutama dalam berita-berita tekait politik. Sementara fakta narasumber perempuan umumnya lebih banyak muncul pada isu-isu seputar gaya hidup, kesehatan atau ibu dan anak karena erat dengan dunia perempuan itu sendiri.

Pertimbangan Berita terkait Gender (Terutama untuk kasus yang rawan bias gender seperti kekerasan seksual atau perkosaan serta pemberitaan perempuan yang ada di balik kasus korupsi)

Berita mengenai kekerasan seksual seperti perkosaan atau pelecehan seksual diakui detik.com dapat menarik pembaca, terutama pembaca laki-laki. Meski begitu, detik.com tidak pernah memuat berita perkosaan yang mendetail dan menyalahkan korban. Dalam kasus yang menyangkut perempuan misalnya kekerasan seksual, lebih ditekankan penerapan Kode Etik Jurnalistik kepada jurnalis di detik.com agar berita yang dihasilkan tidak merugikan perempuan. Berpegang pada kode etik jurnalistik, untuk pemberitaan kasus kekerasan seksual 
83 | Kajian Jurnalisme

ISSN 2549-0559 (cetak) ISSN 2549-1946 (online)

Volume 03 Nomor 01 Tahun 2019

seperti perkosaan dan pelecehan seksual, detik.com juga menyatakan sebisa mungkin memihak korban dan tidak akan mengeksploitasinya.

Detik.com memiliki aturan untuk tidak menceritakan secara detail kasus perkosaan. Untuk diksi atau pilihan kata, meskipun tidak memiliki aturan secara tertulis, pemberitaan biasanya akan menggunakan kata lebih umum dan sebisa mungkin tidak menggunakan katakata yang terlalu kasar. Tak hanya sebatas memberitakan, detik.com juga menyatakan ikut mengawal kasusnya hingga selesai, termasuk juga mengedukasi masyarakat agar kejadian serupa tidak terjadi lagi di kemudian hari.

Mengenai pemberitaan kasus korupsi, detik.com mengungkap bahwa isu ini juga sangat menarik. Pemberitaan dilakukan sebagai tanggung jawab sosial media terhadap pelanggaran atau kejahatan yang dilakukan pelaku korupsi terlepas dia perempuan atau laki-laki. Ketertarikan masyarakat terhadap pemberitaan korupsi terutama ketika menyangkut perempuan juga menurut detik.com karena masih adanya stereotip atau pelabelan tertetu di masyarakat mengenai perempuan, bahwa perempuan tidak seharusnya melakukan perbuatan seperti itu, misalnya. Pertimbangan ketertarikan pembaca yang tinggi akhirnya membuat pemberitaan terhadap kasus seperti ini juga sering dilakukan.

Adanya fakta mengenai perempuan yang ada di balik kasus korupsi yang dilakukan laki-laki juga menurut detik.com menarik bagi masyarakat dan biasanya akan diangkat untuk dijadikan berita. Salah satu pertimbangannya dengan mengangkat angle terkait pelanggaran yang dilakukan si pelaku korupsi dengan perempuan tersebut. Meski begitu, detik.com menyatakan bahwa pihaknya selalu menulis sumber data tersebut dan tidak akan menuliskan fakta yang belum terkonfirmasi benar adanya.

\section{Perubahan Semenjak dipimpin Iin Yumiyanti}

Menurut wartawan detik.com, Iin Yumiyanti lebih sensitif gender dibandingkan dengan pemimpin sebelumnya yang merupakan laki-laki, karena Iin Yumiyanti kerap mengingatkan rekan-rekan sesama wartawannya dalam pemberitaan agar lebih sensitif gender, misalnya terkait penempatan foto. Kendati demikian, detik.com belum menyelenggarakan sendiri pelatihan terkait gender masih karena alasan efisiensi.

"Kalau gender khusus....bisa aja sih tapi belum pernah sih, belum pernah. Tapi tahun ini sepertinya...ini sudah bulan Agustus, September...terus lagi ramai politik gitu kayaknya tahun ini belum (mungkin diadakan pelatihan gender tersendiri). Tapi kita pasti kalau ada pelatihan di luar kita pasti minta ikut, pasti kirim reporter. Itu lebih efisien sih karena kan kita berita harus tetap ada, mengalir. Kan kalau ada pelatihan khusus terus di kantor misalkan berkurang 10 orang, 20 orang pelatihan gitu ya agak mengganggu supply berita. Jadi kita gentian aja sih (untuk ikut pelatihan dari luar) dan setiap tahun tuh pasti AJI selalu ada (pelatihan), jadi gentian ikutnya. Terus nanti pas meeting ya dia yang ikut ini kita suruh cerita, iya sharing gitu," (Sumiati, Wawancara. 24 Agustus 2018). 
Kajian Jurnalisme

ISSN 2549-0559 (cetak) ISSN 2549-1946 (online)

Volume 03 Nomor 01 Tahun 2019

\section{Proses Pembuatan Berita di detik.com}

Dalam sehari detik.com bisa menerima ratusan hingga ribuan artikel atau berita. Untuk detiknews saja, berita yang masuk dalam sehari bisa mencapai 700-1000 berita jika sedang ramai, sementara normalnya bisa mencapai 200-300 berita. Untuk kanal lainnya berkisar 3050 berita. Terdapat enam jalur berita yang masuk ke detik.com: berita lapangan dari wartawan melalui telepon, berita lapangan dari wartawan yang mengikuti seminar, acara atau rapat secara langsung, berita running news, berita riset, berita luar negri dan berita langsung dari narasumber seperti press release.

Detik.com menggunakan media Whatsapp sebagai ruang untuk melakukan rapat redaksi secara cepat. Rapat redaksi umunya dilakukan di pagi hari. Setelah berita diterima oleh redaksi melalui berbagai jalur, berita akan melalui proses verifikasi, pengecekan \& pengeditan oleh editor dan juga redaktur pelaksana maupun pemimpin redaksi jika isu yang dibahas sedang krusial. Setelah itu berita bisa dimuat atau naik. Setelah dimuat, berita juga masih bisa diedit oleh redaktur bahasa jika ditemukan adanya kesalahan tata bahasa.

\section{Penerapan Sensitivitas Gender di detik.com}

Peneliti masih menemukan bias gender dalam kegiatan jurnalistik-yakni pemberitaan-di detik.com. Bias gender ini terkait bahasa atau diksi yang digunakan, terutama dalam kasus perkosaan. Dalam pemberitaan tentang kasus perkosaan, walaupun detik.com menyatakan sudah memiliki kebijakan untuk pilihan kata atau diksi agar tak merugikan korban, masih ada beberapa berita yang masih menggunakan diksi yang terkesan merugikan korban.

Pada beberapa berita, detik.com masih menggunakan istilah yang merugikan korban, misalnya "menggilir", "mencabuli", "digagahi” atau "setubuhi”. Para penentu kebijakan belum memiliki pemahaman yang seragam mengenai diksi yang sensitif gender. Detik.com juga masih menggunakan nama samaran bunga untuk mengganti identitas korban, sesuai dengan kode etik. Selain itu, walaupun dengan pertimbangan menuliskan fakta sebenarnya yang terjadi di lapangan, masih ada juga berita yang memuat fakta-fakta di lapangan yang terkesan menyalahkan korban karena lemah, seperti 'korban tertipu janji manis' (Kusuma, 2017) atau 'korban percaya dengan pelaku yang baru dikenal lewat media sosial' (Fanani, 2017).

Sebagai media massa yang berperan penting dalam sosialisasi gender, detik.com menyatakan bahwa ada beberapa cara yang mereka lakukan agar pemberitaan mereka sensitif gender, diantaranya dengan melakukan pemberitaan yang tidak mendiskriminasi atau mendeskriditkan gender tertentu, terutama perempuan. Misalnya pada pemberitaan kasuskasus kejahatan terkait perempuan detik.com mengingatkan masyarakat agar kejadian yang sama tidak terulang di masa depan. Meski begitu, tak dapat dipungkiri terkadang berita seputar kejahatan seksual misalnya perkosaan, memang seolah merugikan pihak korban. Detik.com sendiri mengaku bahwa terkadang fakta yang ada di lapangan, seperti keterangan dari pihak yang bersangkutan, terutama polisi memang seperti itu adanya sehingga terkadang seolah-olah ikut menyalahkan pihak korban.

Kesan menyalahkan korban terjadi karena dalam kebanyakan kasus perkosaan jurnalis sulit untuk mendapatkan keterangan dari pihak korban yang masih trauma. Pada akhirmya, 
85 | Kajian Jurnalisme

ISSN 2549-0559 (cetak) ISSN 2549-1946 (online)

Volume 03 Nomor 01 Tahun 2019

fakta yang diperoleh memang hanya dari pihak kepolisian. Dalam praktik jurnalistiknya, para penentu kebijakan di tingkat redaksi detik.com mengaku telah berupaya maksimal untuk tidak bias gender, seperti misalnya dengan tidak menyalahkan korban pelecehan seksual, tidak menguraikannya secara detail sehingga mendekati pornografi, serta tidak mengungkap identitas korban. Pemimpin redaksi diakui berperan sebagai sumber yang aktif memberi tahu rekan-rekan kerjanya terhadap hal-hal terkait gender.

Selanjutnya, di tingkatan akhir proses berita yakni pada redaktur bahasa, Habib Rifai menjelaskan ia mengakalinya dengan mencari pilihan kata yang lebih netral sehingga berita menjadi lebih sensitif gender. Meski redaktur bahasa dapat mengedit bahasa dari berita atau artikel yang telah dimuat, dalam kasus tertentu, mereka terkadang tidak berada posisi yang berwenang untuk mengganti pilihan kata secara langsung, karena pola kerja media online yang memiliki faktor SEO (Search Engine Optimization) sehingga membuat mereka tidak bisa dengan mudah mengganti kata yang ada. Karena masih tergolong baru dan minimnya SDM, tidak semua berita atau artikel akhirnya dapat diedit oleh redaktur bahasa. Besar kemungkinan jika banyak berita yang terlewat untuk diedit dari segi bahasanya, apalagi ketika menyangkut bahasa yang sensitif gender. Apalagi ketika berita membludak, fokus utama pengeditan bahasa masih berada di seputar judul berita saja.

Cara kedua agar pemberitaan lebih sensitif gender menurut detik.com adalah dengan memberi ruang dan perhatian lebih untuk mengangkat isu-isu terkait perempuan dalam pemberitaannya. Apalagi detik.com sudah memiliki kanal-kanal khusus yang sangat bisa dimanfaatkan bagi pemberitaan. Selain itu, detic.com kerap melakukan acara-acara di luar kantor yang mendukung perempuan untuk mengaktualisasi diri, misalnya lewat Women's Day yang dilakukan wollipop atau kelas memasak yang dilakukan detikfood.

Detik.com pernah mendapat aduan atau kritikan masyarakat terkait berita mereka yang dinilai kurang sensitif gender. Kebanyakan masyarakat berkomentar lewat media sosial yang dimiliki detik.com. Dalam menghadapi aduan ataupun kritik dari masyarakat tadi, Pemimpin Redaksi Iin Yumiyanti menjelaskan bahwa pihak redaksi biasanya akan melakukan diskusi lanjutan maupun pengambilan suara terkait kelanjutan berita tersebut.

Ketika menemukan berita detik.com yang ternyata memang kurang sensitif gender, pihak redaksi detik.com menjelaskan akan menindaklanjuti dengan memberikan sanksi kepada penulis. Biasanya memang penulis muda yang kebanyakan laki-laki dan belum paham mengenai penulisan terkait gender yang kerap melakukan kesalahan. Sanksi bagi penulis yang menulis berita yang kurang sensitif gender berupa teguran, lalu surat peringatan, mulai dari surat peringatan 1-3, hingga yang paling parah pemecatan. Selama ini belum pernah sampai ada yang dipecat, karena setelah ditegur atau diingatkan para penulis ini akan belajar dan tidak akan mengulangi kesalahannya lagi.

\section{Konsep Gender yang Dianut Para Penentu Kebijakan di Tingkat Redaksional detik.com}

Gender menurut Mansour Faqih (Mukhotib, 1998) merupakan pelabelan jenis kelamin yang pada kenyataannya bisa dipertukarkan antara perempuan dan laki-laki. Misalnya, sifat lembut, kasar, dll. Karena gender sesungguhnya bukanlah kodrat, tetapi merupakan hasil konstruksi 
tradisi, budaya, agama dan ideologi tertentu yang mengenal batas ruang dan waktu sehingga gender sangat tergantung pada nilai-nilai yang dianut masyarakat dan dapat berubah menurut situasi dan kondisi tertentu. Konsep gender adalah sifat yang melekat pada kaum laki-laki dan perempuan yang dibentuk oleh faktor sosial maupun budaya, sehingga lahir beberapa anggapan tentang peran sosial dan budaya laki-laki dan perempuan. (Handayani, 2006)

Berdasarkan hasil penelitian, setiap individu, yakni para penentu kebijakan di tingkat redaksional detik.com, memiliki pemahaman tentang konsep gender yang berbeda, tergantung dari bagaimana faktor-faktor sosial dan budaya yang membentuknya. Hal ini juga menunjukkan bahwa konsep gender sangatlah dinamis. Seperti dijelaskan Narwoko dan Suyanto, gender sebagai suatu konsep merupakan hasil pemikiran atau rekayasa manusia, dibentuk oleh masyarakat sehingga gender bersifat dinamis dapat berbeda karena perbedaan adat istiadat, budaya, agama, dan sistem nilai dari bangsa, masyarakat, dan suku bangsa tertentu (Narwoko \& Suyanto, 2011).

Meskipun keempat penentu kebijakan memiliki latar belakang agama yang sama, keempatnya memiliki konsep gender yang berbeda. Begitu juga dengan latar belakang budaya. Meskipun Iin Yumiyanti dan Elvan Danny memiliki latar belakang suku yang sama, yakni suku Jawa, keduanya justru dibesarkan dengan konsep gender yang berbeda.

Beragamnya konsep gender yang dianut para penentu kebijakan di atas menunjukkan beragamnya ideologi gender yang dianut di Indonesia. Ideologi gender yang ada di Indonesia begitu beragam sesuai dengan keragaman yang dimiliki masyarakatnya, baik dari aspek etnik, keagamaan, maupun ekonomi. Indonesia terdiri dari berbagai kelompok etnis (Herawati, 2016). Menurut Linda P. Farid gender dipelajari melalui proses sosialisasi dan kebudayaan masyarakat tertentu dan bisa berubah. Gender ini selalu berubah sesuai dengan kondisi atau wilayah setempat (Mukhotib, 1998).

Perubahan inilah yang dialami Andi Sururi. Meskipun dalam berumah tangga ia masih memiliki pemahaman gender yang terkesan 'konservatif' karena menganggap perempuan tidak harus bekerja, dengan bekerja di lingkungan yang tidak lagi mempermasalahkan perbedaan perempuan dan laki-laki ketika bekerja, ia mengaku stereotype atau pelabelan tentang ranah jurnalistik yang sangat maskulin yang semula dianutnya akhirnya bisa berubah.

Begitu juga dengan apa yang dialami Iin Yumiyanti. Dengan berbagai pengalamannya akan perlakuan ketidakadilan karena konsep gender yang dipahami keluarganya di masa kecil, ia menjadi tertarik untuk mempelajari lebih lanjut tentang gender. Ia juga mengaku suka membaca hal-hal atau buku tentang perempuan, gender dan feminisme, bahkan mengikuti pelatihan gender secara mandiri, sehinggga tertarik untuk membahas dan meliput masalahmasalah terkait gender. Di antaranya ketika ia meliput tentang penyiksaan TKI di Saudi Arabia, Sumiati yang sangat menyedihkan.

Kesadaran cukup sensitif gender yang dimiliki Iin Yumiyanti ini sesuai dengan pembahasan hasil penelitian Tim LP3Y (Siregar, Pasaribu, \& Prihastuti, 1999) bahwa kesadaran gender yang sensitif di kalangan wartawan masih relatif baru dan baru menggejala di beberapa benak wartawan yang kebanyakan adalah berjenis kelamin perempuan. Kesadaran gender ini tumbuh dan berkembang secara individual dalam diri beberapa wartawan dan bukan 
87| Kajian Jurnalisme

ISSN 2549-0559 (cetak) ISSN 2549-1946 (online)

Volume 03 Nomor 01 Tahun 2019

muncul secara kolektif. Kemudian, kesadaran gender secara individual yang berkembang di benak beberapa jurnalis perempuan ini adalah bukan sebagai suatu reaksi maupun refleksi dari persoalan problematik internal organisasi yang sering mereka hadapi sehari-hari, tetapi lebih karena pergaulan sosial wartawan, pengalaman meliput, mengikuti konferensi/ seminar nasional maupun internasional tentang perempuan atau karena membaca buku-buku.

Cara pandang dan persepsi diri para jurnalis perempuan terhadap kapasitas, kedudukan dan lingkungan kerja serta dunia kehidupan yang lebih luas cukup mempengaruhi pola dan hasil kerja mereka. Dengan kata lain, pengalaman subjektif jurnalis perempuan akan mempengaruhi lahirnya karya-karya jurnalistik yang sensitif gender atau sebaliknya karyakarya jurnalistik yang stereotype (Siregar et al., 1999).

\section{Kebijakan Redaksional detik.com Terkait Gender}

Berdasarkan hasil penelitian, secara umum detik.com tidak pernah memandang perbedaan gender sebagai suatu masalah dalam urusan pekerjaan. Dunia jurnalistik di detik.com tidak lagi dipandang sebagai ranah yang maskulin atau feminin.

Menurut Houtman Tahrun dan Nasir, profesi jurnalis adalah profesi yang tidak memperlakukan pembedaan berdasarkan jenis kelamin. Pria maupun wanita, punya kesempatan yang sama untuk menjalani profesi ini. Dimana pun ditempatkan dan sebagai posisi apapun, kesempatan yang diberikan bukanlah mengacu kepada unsur gender, tetapi lebih kepada penilaian profesional. (Tahrun \& Nasir, 2016)

Dalam hal pembagian dan kesempatan kerja, detik.com juga sudah tidak lagi membagi pekerjaan berdasarkan sex line, semuanya dilakukan berdasarkan profesionalitas. Model kerja yang sex line merupakan model kerja di mana pekerja laki-laki dan perempuan ditempatkan pada bidang kerja yang dianggap cocok berdasarkan konstruksi sosial selama ini. Dalam hal ini, jurnalis laki-laki ditempatkan pada bidang kerja yang dianggap "maskulin" sementara jurnalis perempuan ditempatkan pada bidang kerja yang dianggap "feminin". Pembagian kerja atau liputan di detik.com bukan berdasarkan pertimbangan bidang kerja maskulin atau feminin, melainkan berdasarkan profesionalitas dan pertimbangan rasional. (Siregar et al., 1999)

Dalam buku Media dan Gender disebutkan bahwa cara pembagian kerja sex line membuat jurnalis perempuan sangat sulit menduduki jabatan-jabatan strategis yang mensyaratkan wartawan yang berpengalaman dalam liputan keras ataupun lunak (Siregar et al., 1999). Di detik.com, jurnalis perempuan sebenarnya tidak sulit untuk menduduki jabatan strategis. Semua kesempatan diberikan kepada mereka yang memang memiliki kemampuan. Hal ini pun bisa dilihat dari struktur redaksinya yang sudah banyak diisi perempuan pada tingkat pemegang keputusan, seperti pada jabatan Pemimpin Redaksi, Wakil Redaktur Pelaksana detiknews, dan Redaktur Pelaksana detikhot, detikhealth, Wollipop, detikfood, maupun detiktravel. Namun, harus diakui, jumlahnya memang tidak sebanyak jurnalis lakilaki.

Pertimbangan berdasarkan profesionalisme dan rasional ini membuat organisasi media detik.com bisa dibilang sudah memiliki kesadaran kolektif yang sensitif gender. Kesadaran kolektif yang sensitif gender dalam organisasi media berarti kesadaran di mana struktur, posisi, 
peran dan relasi antar wartawan dalam suatu organisasi media yang tercipta lebih karena kapasitas professional dan kesepakatan yang rasional, tidak berdasarkan garis-garis yang seksis. Seseorang ditempatkan dalam posisi redaksional tertentu bukan karena dia seorang lakilaki atau perempuan, tetapi lebih karena kapasitas professional atau karena kesepakatan yang rasional. Seorang wartawan ditugaskan untuk meliput peristiwa tertentu bukan karena dia seorang laki-laki atau perempuan, tetapi lebih karena kapasitas professional atau karena kesepakatan yang rasional(Siregar et al., 1999).

Mengenai fasilitas yang diberikan detik.com sebenarnya sudah memadai. Pertimbangan tidak piket malam selama dua tahun bagi jurnalis perempuan yang masih memiliki anak kecil juga sangat rasional. Adanya cuti menstruasi atau haid selama 2 hari yang diberikan kepada pekerja perempuan sudah sesuai dengan Undang-Undang No. 13 Tahun 2003 Pasal 81. Begitu juga dengan cuti melahirkan selama 3 bulan, sudah sesuai dengan peraturan dalam Undangundang No. 13 Tahun 2003 tentang Ketenagakerjaan Pasal 82 ayat (1).

Kebijakan redaksi terkait gender dalam melakukan kegiatan jurnalistiknya, detik.com berpegang teguh pada kode etik jurnalistik dan pedoman media siber yang telah diatur oleh Dewan Pers, ditambah pedoman yang telah disusun perusahaan dalam buku putih detik.com. Meski begitu, detik.com masih belum memiliki pedoman khusus secara tertulis agar berita yang dihasilkan yang sensitif gender. Untuk melakukan pemberitaan agar sensitif gender, terutama pada kasus-kasus pelecehan seksual agar tidak merugikan korban, detik.com masih berpedoman pada kode etik jurnalistik, terutama pasal 5 dan pasal 8 .

Berpedoman kepada kode etik saja belum cukup untuk mewujudkan sensitivitas gender dalam pemberitaan. Seperti apa yang disampaikan Houtman dan Nasir bahwa kesepakatan yang dimuat dalam kode etik memang tidak menyinggung perbedaan gender. Yang ditekankan adalah bagaimana insan jurnalis itu harus menjamin informasi yang benar, akurat, valid dan tidak merugikan orang banyak serta harus diverifikasi dan berimbang. (Tahrun \& Nasir, 2016)

Pelatihan terkait gender juga belum pernah diselenggarakan di detik.com. Padahal, pelatihan terkait gender ini merupakan salah satu cara terbaik untuk meningkatkan sensitivitas gender dan mengurangi bias gender dalam media massa (Siregar et al., 1999). Pelatihan ini menjadi satu cara awal untuk menanamkan pemahaman konsep gender yang seragam bagi seluruh jurnalis. Apalagi berdasarkan hasil penelitian, belum semua penentu kebijakan memiliki pemahaman yang sama terkait gender. Untuk itu, pelatihan jurnalistik terkait gender sangatlah diperlukan bagi detik.com.

Hal yang sama diutarakan Agnes Aristiarini mengenai pentingnya pelatihan terkait gender untuk menyamakan persepsi wartawan dan mengubah pemahaman gender yang lama dalam media massa. Agnes menjelaskan:

“...training jurnalistik yang berspektif gender menjadi mutlak diperlukan untuk mengubah masyarakat masuk dalam tatanan baru, masyarakat yang memandang kedudukan laki-laki dan perempuan dengan setara. Salah satu cara yang dapat dilakukan memang dengan menyamakan persepsi para wartawan dan media massa ini dengan pemahaman baru terhadap posisi perempuan." (Mukhotib, 1998) 
89| Kajian Jurnalisme

ISSN 2549-0559 (cetak) ISSN 2549-1946 (online)

Volume 03 Nomor 01 Tahun 2019

Di detik.com, pembaca menjadi pertimbangan untuk kebijakan pemuatan berita yang dimiliki detik.com. Selain news value atau nilai berita, pembaca menjadi pertimbangan yang sangat kuat. Hasil wawancara dengan para penentu kebjakan pun menunjukkan bahwa pemberitaan terkait kasus pelecehan seksual seperti perkosaan dan korupsi sangat diminati pembaca detik.com. Menurut Yusuf, hal-hal yang disenangi khalayak, seperti hal yang mengandung unsur sex and crime juga merupakan syarat utama berita, yakni kecocokan dengan apa yang diinginkan khalayak. Maka tak heran jika unsur tersebut sering muncul dalam pemberitaan di media (Yusuf, 2004).

Media online memperoleh penghasilan lewat iklan yang didapatkan dengan menawarkan traffic. Sederhananya traffic adalah aktivitas pada satu halaman situs yang dihasilkan dari kunjungan pengguna internet dan aktivitas pengguna internet di halaman itu. Semakin banyak sebuah situs dikunjungi dan semakin banyak aktivitas yang dilakukan pengguna internet di laman-laman situs itu, maka traffic situs itu semakin tinggi. (Margianto \& Saefullah, 2012). Dengan pola bisnis media online seperti itu, maka tak mengherankan pula jika detik.com memiliki kebijakan untuk terus memberitakan kasus dengan pembaca yang tinggi seperti kasus pelecehan seksual, perkosaan dan korupsi. Namun, tidak semua pemberitaan terkait kasus-kasus tersebut sudah sensitif gender.

\section{Sensitivitas Gender Detik.com}

Sensitif berasal dari kata kerja sentire (bahasa latin) yang artinya menyerap dengan indera, mengalami atau merasai. Ada konotasi mengenai kelekatan fisik, yang menimbulkan reaksi dan keterikatan pribadi (sikap dan tindakan). Dengan demikian, sensitif dapat dipahami sebagai sebuah sifat keterkaitan yang terus menerus yang pada suatu saat bahkan menjadi sebuah bagian dari kepribadian (Mukhotib, 1998).

Penilaian sensitif gender ini menurut Atik (dalam (Mukhotib, 1998) bisa dilakukan dengan tiga tahap, pertama dengan melihat kuantitas jurnalis perempuannya. Kedua, dengan melihat kualitas pemberitaan mengenai perempuan. Ketiga, dengan melihat kebijakan (kepentingan) lembaga pers masing-masing.

Tahap pertama, kuantitas jurnalis perempuan. Di detik.com jumlah jurnalis perempuan masih lebih sedikit dibanding jurnalis laki-laki. Berdasarkan pengamatan peneliti dari susunan redaksi yang terpampang di laman web detik.com, dari total 175 jurnalis, jumlah jurnalis lakilaki masih mendominasi yakni 120 orang $(68,57 \%)$, sementara perempuan berjumlah 55 orang (31,43\%). Di tahap kedua, kualitas pemberitaan mengenai perempuan di detik.com. Seperti yang telah dijelaskan dalam hasil penelitian, masih ditemukan beberapa berita yang masih tergolong bias gender di detik.com, terutama mengenai kasus seperti pelecehan seksual atau perkosaan. Bias gender yang ditemukan biasanya karena penggunaan bahasa/ diksi yang masih terkesan merugikan korban.

Di sisi lain, di detik.com juga mulai muncul beberapa artikel yang cukup sensitif gender. Artikel tersebut lebih banyak masih berada di bawah kanal bertema gaya hidup seperti detikhot, wollipop atau detikhealth, bukan detiknews. Selain di kanal gaya hidup, satu atau dua artikel 
sensitif gender juga bisa ditemui di detiksport dan detikX. Munculnya artikel yang sensitif gender nampaknya bukan sepenuhnya dipengaruhi pemimpin redaksi. Pemberitaan sensitif gender atau tidak sensitif gender di detik kembali kepada individu yang menulis.

Tahap terakhir, tahap ketiga, mengenai kebijakan redaksional detik.com. Terkait dengan kebijakan redaksional detik.com ini, terutama untuk mengukur komitmen detik.com dalam mempraktikkan sensitif gender di kelompok/ organisasi medianya, lebih lanjut peneliti menggunakan indikator sensitif gender yang disusun United Nations Educational, Scientific and Cultural Organisation (UNESCO) dalam kategori A: Langkah-langkah untuk mendorong kesetaraan gender di media, terdapat langkah "Organisasi Media Mendorong Penerapan Kode Etik/Kebijakan Editorial yang Mendukung Kesetaraan Gender dalam Pemberitaan”. Fokus dari indikator ini yakni untuk mengukur komitmen lembaga untuk mempraktikkan sensitif gender di kelompok/ organisasi media terkait konten dengan tujuan: integrasi kesadaran gender dalam praktik media melalui penerapan kebijakan dan membangun inisiatif mendorong jurnalis sadargender, juga pada personel kreatif/teknis lain yang berkontribusi terhadap produksi konten media.

Dari total 14 indikator yang ada, sebagian besar indikator belum ditemukan di detik.com. Baru 5 indikator sudah dipraktikkan di detik.com, sementara sisanya belum sama sekali ada atau sudah ada tapi belum dilaksanakan secara keseluruhan. Indikator yang sudah dilaksanakan ini di antaranya: keberadaan sumber untuk kepentingan pemberitaan sensitif gender seperti buku panduan, direktori/ daftar narasumber para pakar perempuan diberbagai bidang, daftar narasumber individu atau badan yang memiliki perspektif gender; mekanisme internal pemantaun konten media secara terus-menerus melibatkan publik. Misalnya dengan menyiapkan forum, agar masyarakat dapat melakukan pengaduan atau kritik terkait isu kesetaraan gender dalam pemberitaan; publikasi atas kebijakan gender dan pelaporan rutin mengenai daya tanggap kelembagaan terhadap pengaduan atau persepsi atas kinerja pada isuisu gender; Ketaatan pada kebijakan sensitif gender terkait konten media, dapat digunakan sebagai salah satu penilaian kinerja dan salah satu pertimbangan kenaikan jabatan; mengakui keberadaan organisasi independen (atau setara dengan itu) sebagai mekanisme eksternal memberikan akses bagi publik-, dengan membentuk forum bagi publik menyalurkan pengaduan dan kritik mengenai konten media; serta ulasan data monitoring dan tindakan atas pelbagai masalah signifikan.

Secara keseluruhan, berdasarkan penilaian sensitif gender menurut Atik Nurbaiti dengan melihat 3 tahap yang telah dijelaskan di atas, detik.com masih kurang sensitif gender, terutama dalam kualitas pemberitaan mengenai perempuan karena masih adanya berita-berita yang kurang sensitif gender (seperti dalam berita kasus perkosaan) dan di tahap ketiga terkait kebijakan (kepentingan) lembaga, detik.com juga masih belum berkomitmen secara penuh untuk menerapkan sensitivitas gender di dalam kebijakan lembaganya.

Kurangnya kesadaran gender dan sensitivitas gender di kalangan para penentu kebijakan ini nampaknya menjadi alasan utama mengapa detik.com masih terbilang bias gender. Keterkaitan bias gender dengan kurangnya kesadaran dan sensitif gender di kalangan pengelola media ini : 
91| Kajian Jurnalisme

ISSN 2549-0559 (cetak) ISSN 2549-1946 (online)

Volume 03 Nomor 01 Tahun 2019

“Apabila kita meyakini asumsi bahwa orientasi media amat dipengaruhi oleh bagaimana visi dan persepsi atau orientasi etis para pengelola media terhadap dunia kehidupan, maka kurangnya kesadaran gender dan sensitif gender di kalangan pengelola media cenderung melahirkan pemberitaan yang bias gender. Atau setidaktidaknya, banyak peristiwa atau persoalan yang sensitif gender dalam masyarakat yang terluput dari perhatian para wartawan menulis berita maupun ketika menentukan angle tulisannya." (Siregar et al., 1999)

Kurangnya sensitif gender ini terjadi juga karena detik.com masih menerapkan konsep jurnalisme konvensional, di antaranya dapat dilihat dari pemberitaan yang bersifat sangat objektif, netral; tujuan peliputan dan penulisan yang masih sebatas pemaparan dan penjelasan apa adanya; berita adalah refleksi dari realitas sosial yang ada karenanya berita harus bisa mencerminkan realitas sosial yang diberitakan secara utuh; jurnalis sebagai bagian dari tim untuk mencari kebenaran: dan hasil peliputan bersifat eksplanasi, prediksi dan kontrol. Jurnalisme konvensional ini dianggap tidak mempertimbangkan aspek-aspek gender (Sarwono, 2013). Hasil liputan atau pemberitaan yang muncul pun menjadi bias gender karena jurnalisnya pun belum memiliki perspektif maupun sensitivitas gender yang memadai.

Dalam jurnalisme berperspektif gender, jurnalis memiliki peran sebagai aktivis atau partisipan dari kelompok-kelompok yang marginal (khususnya perempuan) yang ada dalam masyarakat. Jurnalis juga berperan sebagai pekerja yang memilki proses berbeda dalam kelaskelas sosial. Tujuan peliputan dan penulisan adalah untuk pemihakan dan pemberdayaan kepada kelompok-kelompok marginal, khususnya perempuan. Hasil liputan pada akhirnya akan mereflesikan ideologi jurnalis dan "subjektif" karena merupakan bagian dari kelompokkelompok marginal yang diperjuangkan. Hasil peliputan bersifat kritis, transformatif, emansipatif dan pemberdayaan sosial dan memakai bahasa yang sensitif gender dengan pemihakan yang jelas (Sarwono, 2013).

Terakhir, terkait peran perempuan terhadap media yang lebih sensitif gender, peneliti menggunakan pembahasan gender dan media dari Hanitzsch \& Hanusch (Hanitzsch \& Hanusch, 2012) di antara dua perdebatan terkait peran gender dalam praktik jurnalistikapakah mempengaruhi atau tidak. Keduanya menyimpulkan bahwa gender memang mungkin saja menjadi salah satu kekuatan yang mempengaruhi jurnalis perempuan dan laki-laki untuk berpikir dan bersikap berbeda. Hal ini karena gender berada dalam pandangan profesional dan sikap seseorang yang sangat tertanam di dalam konteks organisasional dan konteks sosial. Pada akhirnya, sangat mungkin jika jurnalis perempuan memiliki perbedaan nilai professionalyang mungkin feminis - di dalam ruang redaksi yang diisi oleh presentase perempuan yang lebih tinggi.

\section{Simpulan}

Masing-masing penentu kebijakan memiliki konsep gender individual yang berbeda. Masih ada yang berpendapat bahwa ada pembagian peran-peran gender. Pemahaman mengenai konsep gender yang dianut para penentu kebijakan sebagian besar sangat dipengaruhi oleh keluarga dan agama. Konsep gender yang dimiliki ini pun tidak berlaku mutlak, sangat dinamis dan bisa terus berubah seiring waktu. Sementara di tempat kerjanya, semua penentu kebijakan 
Kajian Jurnalisme

ISSN 2549-0559 (cetak) ISSN 2549-1946 (online)

Volume 03 Nomor 01 Tahun 2019

tidak lagi mempersoalkan perbedaan gender.

Detik.com sebenarnya tidak memiliki kebijakan tertulis secara khusus terkait gender di tempat kerja. Secara umum, rekrutmen, pembagian dan pemberian fasilitas kerja dilakukan berdasarkan profesionalitas dan rasionalitas. Ruang laktasi belum tersedia dan pemberian asuransi yang diterima perempuan dan laki-laki masih berbeda. Pelatihan khusus terkait gender juga belum pernah diselenggarakan. Untuk kebijakan terkait kerja jurnalistik, detik.com berpedoman kepada kode etik jurnalistik dan pedoman media siber ditambah pedoman yang ada dalam buku putih yang disusun redaksi. Pertimbangan detik.com untuk berita terkait gender yang rawan bias gender seperti kasus perkosaan atau kasus korupsi dan perempuan diantaranya: melakukan pemberitaan dengan didasari fakta, berita harus memiliki nilai berita yang kuat dan menarik pembaca, harus taat pada kode etik jurnalistik, untuk berita perkosaan tidak detail, tidak menyalahkan korban, tidak mengungkap identitas korban, menggunakan diksi yang lebih umum dan tidak kasar, mengawal kasus hingga selesai dan mecantumkan fakta hukum maupun fakta persidangan. Untuk berita korupsi dan perempuan: angle menjelaskan pelanggaran yang dilakukan dan tidak menulis fakta yang belum terkonfirmasi atau gossip.

Para penentu kebijakan masih kurang menerapkan sensitif gender dalam pelaksanaan kegitaan jurnalistiknya. Meskipun disebutkan sudah ada aturan tidak tertulis terkait pemberitaan sensitif gender, masih ada berita yang bias gender karena menggunakan diksi yang tidak sensitif gender. Selain karena belum seragamnya pemahaman terkait pemberitaan yang sensitif gender, para penentu kebijakan ini terkadang belum mempraktikkan sensitivitas gender karena terhalang pola kerja dan pola bisnis media online. Secara keseluruhan detik.com juga masih mempraktikkan pola kerja jurnalisme konvensional, belum jurnalisme berperspektif gender. Detik.com juga masih belum berkomitmen secara penuh untuk menerapkan sensitivitas gender di dalam kebijakan lembaganya. Dari 14 indikator sensitif gender yang disusun United Nations Educational, Scientific and Cultural Organisation (UNESCO) mengenai komitmen lembaga untuk mempraktikkan sensitif gender di kelompok/ organisasi media terkait konten, baru 5 indikator yang sudah dipraktikkan di detik.com, sementara sisanya belum sama sekali ada atau sudah ada tapi belum dilaksanakan secara menyeluruh.

\section{Daftar Pustaka}

Aprilia, E. N., \& Jannah, R. (2014). Konstruksi Identitas Korban dan Pelaku Pemerkosaan di Media Online Detik . com. 1(I), 110-128.

Bungin, B. (2008). Penelitian Kualitatif. Jakarta: Kencana Prenada Media Group.

Fanani, A. (2017). Gadis Bawah Umur Diperkosa Pemuda yang Baru Dikenalnya di Medsos. Retrieved September 19, 2017, from www.detik.com website: https://news.detik.com/berita-jawa-timur/d-3776808/gadis-bawah-umur-diperkosapemuda-yang-baru-dikenalnya-di-medsos/komentar

Handayani, T. S. (2006). Konsep dan Teknik Penelitian Gender. Malang: UMM Press.

Hanitzsch, T., \& Hanusch, F. (2012). Does gender determine journalists' professional views? A reassessment based on cross-national evidence. European Journal of Communication, 27(3), 257-277. https://doi.org/10.1177/0267323112454804

http://jurnal.unpad.ac.id/kajian-jurnalisme 
93 | Kajian Jurnalisme

ISSN 2549-0559 (cetak) ISSN 2549-1946 (online)

Volume 03 Nomor 01 Tahun 2019

Herawati, M. (2016). Pemaknaan Gender Perempuan Pekerja Media. Jurnal Kajian Komunikasi, 4(1), 85-95. https://doi.org/10.24198/jkk.vol4n1.8

Herdiansyah, H. (2012). Metode Penelitian Kualitatif untuk Ilmu-Ilmu Sosial. Jakarta: Salemba Humanika.

Ilyas, W. J. (2015). Perempuan dan Korupsi: Seksisme Dalam Pemberitaan Media Online. Jurnal Masyarakat Dan Budaya, 17(3), 271-284.

Kusuma, E. F. (2017). Iming-imingi Jadikan Model, Pria di Bekasi Ini Malah Perkosa Korban. Retrieved August 23, 2017, from www.detik.com website: https://news.detik.com/berita/d-3611753/iming-imingi-jadikan-model-pria-di-bekasiini-malah-perkosa-korban

Luviana. (2012). Jejak Jurnalis Perempuan. Jakarta: Aliansi Jurnalis Independen.

Margianto, J. H., \& Saefullah, A. (2012). Media Online: Pembaca, Laba dan Etika. Jakarta: Aliansi Jurnalis Independen.

Moleong, L. J. (2017). Metodologi Penelitian Kualitatif (Edisi Revisi). In PT. Remaja Rosda Karya (p. 424).

Mukhotib. (1998). Menggagas Jurnalisme Sensitif Gender. Yogyakarta: PMII-INPI Pers.

Mulyana, D. (2010). Metodologi Penelitian Kualitatif. Bandung: PT Remaja Rosdakarya.

Narwoko, J. D., \& Suyanto, B. (Eds.). (2011). Sosiologi Teks Pengantar dan Terapan Edisi Ketiga.

Prasetyo, Y. A. (2016). Media Harus Peka Perspektif Gender.

Sarwono, B. K. (2013). Saatnya Media Pro Perempuan. Depok: Departemen Ilmu Sosial dan Ilmu Politik Universitas Indonesia.

Siregar, A., Pasaribu, R., \& Prihastuti, I. (Eds.). (1999). Media dan Gender: Perspektif Gender Atas Industri Surat Kabar Indonesia. Yogyakarta: LP3Y.

Sutarso, J. (2012). Perempuan, Kekuasaan dan Media Massa: Sebuah Studi Pustaka. KomuniTi, $\operatorname{IV}(1)$.

Tahrun, H., \& Nasir, M. (2016). Keterampilan Pers dan Jurnalistik Berwawasan Gender. Yogyakarta: Deepublish.

Yusuf, I. A. (2004). Peningkatan Kepekaan Gender dalam Jurnalisme. Jurnal Ilmu Sosial Dan Ilmu Politik, 7(3). 